\title{
Analisis Dampak Ekonomi Wisata Hiu Paus Terhadap Pendapatan Masyarakat Batubarani Gorontalo
}

\author{
Eduart Wolok* \\ Universitas Negeri Gorontalo
}

\begin{abstract}
This study aims to determine the economic impact of Whale Sharks travel to revenue of Batubarani villagers in Gorontalo . This study was conducted in January-May 2016. Data collection was done by direct observation using questionnaires. The economic impact was analyzed by using Keynesian Income Multiplier . The results showed that the impact of whale sharks travel to people's income Batubarani at the high category . Income Keynesian Multiplier value is 1:52, Type 1 Income Multiplier Ratio is 1.61 and Type 2 Income Multiplier Ratio is 1.97 .
\end{abstract}

Keywords : Batubarani, sharks, whales, Keynesian Income Multiplier

\section{PENDAHULUAN}

Efek positif akibat dari berkembangnya sektor pariwisata antara lain dapat menurunkan angka pengangguran dan menciptakan lapangan pekerjaan bagi masyarakat sekitar obyek wisata tersebut. Adanya perkembangan sektor pariwisata juga dapat menciptakan lapangan kerja di sektor lain yang terkait, dan dapat meningkatkan pendapatan serta standar hidup masyarakat. Selain itu, efek positif lain dari sektor pariwisata adalah dapat meningkatkan cadangan devisa suatu negara (Yoeti, 2008 dalam Nurfiana, 2013).

Desa Batubarani adalah wilayah berpenduduk yang berpencaharian sebagai nelayan. Desa ini dikejutkan dengan munculnya kawanan hiu paus yang senang berenang dekat dengan wilayah pantai di desa tersebut. Hadirnya kawanan ini awalnya hanya menjadi tontonan masyarakat sekitar. Beriringan waktu, kawanan hiu paus menjadi daya tarik tersendiri oleh masyarakat luas sehingga wilayah ini seperti disulap menjadi daerah wisata. Kondisi ini dimanfaatkan sebaik-baiknya oleh masyarakat sekitar untuk mencari penghasilan lain.

Hadirnya penelitian ini ditujuakn untuk menganalisa dampak wisata hiu paus terhadap pendapatan masyarakat Desa Batubarani Provinsi Gorontalo

\footnotetext{
* Korespondensi : Universitas Negeri Gorontalo, Jln Jendral Sudirman No 6 Kota Gorontalo, Email : eduart@ung.ac.id.
} 


\section{TINJAUAN PUSTAKA}

Wisata bahari adalah segala aktivitas wisata yang menjadikan sumber daya alam laut beserta segala potensinya sebagai suatu daya tarik yang unik untuk dinikmati (Gautama, 2011). Wisata Bahari merupakan wisata yang banyak dikaitkan dengan danau, pantai, atau laut. Wisata bahari adalah suatu kunjungan ke objek wisata, khususnya untuk menyaksikan keindahan lautan, menyelam dengan perlengkapan selam lengkap (Pandit, 1994: 19 dalam Anggraini, 2014).

Analisis dampak ekonomi kegiatan pariwisata umumnya berfokus pada perubahan penjualan, penghasilan, dan penempatan tenaga kerja yang terjadi akibat kegiatan pariwisata. Pada dasarnya analisis dampak ekonomi pariwisata menelusuri aliran uang dari belanja wisatawan, yaitu: (1) Kalangan usaha dan badan-badan pemerintah selaku penerima pengeluaran wisatawan, (2) Bidang usaha lainnya selaku pemasok (supplier) barang dan jasa kepada usaha pariwisata, (3) Rumah tangga selaku penerima penghasilan dari pekerjaan dibidang periwisata dan industri penunjangnya, (4) Pemerintah melalui berbagai pajak dan pungutan (resmi) dari wisatawan, usaha dan rumah tangga (Milasari, 2010).

Menurut Clement dalam Yoeti (2008) dalam Nurfiana (2013) ketika wisatawan mengunjungi suatu tempat tujuan wisata, wisatawan tersebut pasti akan membelanjakan uang mereka untuk memenuhi kebutuhan dan keinginan selama melakukan kunjungan. Uang yang dibelanjakan tersebut tidak berhenti beredar, tetapi berpindah dari tangan yang satu ke tangan yang lain selama periode tertentu. Hal inilah yang dinamakan efek pengganda (multiplier effect).

Proses multplier effect adalah proses yang menunjukkan sejauh mana pendapatan nasional akan berubah efek dari perubahan dalam pengeluaran agregat. Multiplier bertujuan untuk menerangkan pengaruh dari kenaikan atau kemerosotan dalam pengeluaran agregat ke atas tingkat keseimbangan dan terutama ke atas tingkat pendapatan nasional. Keunikan industri pariwisata terhadap perekonomian adalah berupa dampak ganda (multiplier effect) dari pariwisata terhadap ekonomi (Ismayanti, 2010 dalam Belinda, 2013).

Nilai multiplier ekonomi merupakan nilai yang menunjukan sejauh mana pengeluaran wisatawan akan menstimulasi pengeluaran lebih lanjut, sehingga pada akhirnya meningkatkan aktivitas ekonomi di tingkat lokal. Menurut terminologi, terdapat tiga efek multiplier, yaitu efek langsung (direct effect), efek tidak langsung (indirect effect) dan efek lanjutan (induced effect).Ketiga efek ini digunakan untuk menghitung ekonomi yang selanjutnya digunakan untuk mengestimasi dampak ekonomi di tingkat lokal (Prasetio, 2011).

\section{METODE PENELITIAN}

Penelitian dilaksanakan mulai bulan Januari-Mei 2016 di Desa Batubarani Gorontalo. Dipilihnya lokasi ini karena perubahan secara drastis wilayah yang 
diakibatkan olehh munculnya kawanan hius paus di desa tersebut, sehingga dengan singkat wilayah ini berubah menjadi wilayah wisata.

\subsection{Pengumpulan data}

Pengumpulan data dilakukan dengan cara pengamatan/observasi langsung situasi dan kondisi yang terjadi dalam wilayah penelitian. Pengumpulan data dilakukan dengan teknik sebagai berikut :

1. Studi literatur

Metode studi literatur dalam penelitian ini bertujuan untuk memperoleh data berupa kondisi umum wilayah, data-data mengenai jumlah wisatawan, demografi masyarakat dan data tentang perkembangan ekonomi kawasan (supply dan demand).

2. Wawancara

Wawancara dalam penelitian ini adalah pengumpulan data dengan cara menanyakan secara langsung kepada masyarakat yang terdapat di sekitar kawasan wisata baik masyarakat yang terlibat dan tidak terlibat kegiatan wisata, denganpedoman pertanyaan yang disusun secara sistematik sebelumnya. Wawancara yang dilakukan dimaksudkan untuk mendapatkan data secara keseluruhan yang mencakup mata pencaharian, pendapatan, biaya pengeluaran, pendidikan, umur, jenis kelamin serta mengetahui mengenai dampak ekonomi wisata bahari Desa Olele terhadap pendapatan masyarakat.

3. Kuisioner

Untuk kegiatan wawancara dengan wisatawan dilakukan dengan menggunakan kuisioner secara langsung. Kuisioner diberikan bertujuan untuk karakteristik responden yang terdiri dari umur, daerah asal, pendidikan, pendapatan, pengeluaran serta dampak yang dihasilkan setelah terbukanya kawasan wisata tersebut.

4. Pengamatan lapang / observasi

Observasi adalah pengambilan data dengan cara pengamatan langsung di lapangan untuk mendapatkan gambaran yang jelas tentang kondisi atau keadaan objek kajian dengan cara mengunjungi seluruh kawasan wisata dan melihat keseluruhan kondisi kawasan secara langsung, baik kondisi fisik, sarana dan prasarana, aktifitas wisatawan serta sumberdaya manusia pengelolaannya. Selain itu, untuk menyesuaikan data-data yang diperoleh dari hasil studi literatur dengan keadaan yang ada.

\subsection{Pengambilan Sampel}

Responden dalam penelitian ini dibagi menjadi 2 (dua) kategori yaitu wisatawan dan masyarakat yang berada di Desa Batubarani, baik masyarakat yang terlibat dan masyarakat yang tidak terlibat dengan jumlah sample sebanyak 150 sampel. 


\subsection{Analisis Data}

Dampak ekonomi ini diukur dengan menggunakan efek pengganda (multiplier) dari arus uang yang terjadi. Menurut Vanhove (2005) dalam Dritasto (2013) Dalam mengukur dampak ekonomi suatu kegiatan wisata terhadap pendapatan masyarakat lokal terdapat dua tipe pengganda, yaitu:

a. Keynesian Local Income Multiplier,

b. Ratio Income Multiplier,

Menurut Monoarfa (2016) Secara matematis dapat dirumuskan :

Keynesian Local Income Multiplier $=\frac{D+N+U}{E}$

Ratio Income Multiplier, Tipe $I \quad=\frac{D+U}{D}$

Ratio Income Multiplier, Tipe II $=\frac{D+N+U}{D}$

Dimana:

E : Tambahan pengeluaran wisatawan (rupiah)

D : Pendapatan lokal yang diperoleh secara langsung dari E (rupiah)

$\mathrm{N}$ : Pendapatan lokal yang diperoleh secara tidak langsung dari E (rupiah)

$\mathrm{U}$ : Pendapatan lokal yang diperoleh secara induced dari E (rupiah)

Menurut Dritasto (2013) nilai Keynesian Local Income Multiplier, Ratio Income Multiplier Tipe I, Ratio Income Multiplier Tipe II memiliki kriteria-kriteria sebagai berikut:

a. Apabila nilai-nilai tersebut kurang dari atau sama dengan nol $(\leq 0)$, maka lokasi wisata tersebut belum mampu memberikan dampak ekonomi terhadap kegiatan wisatanya,

b. Apabila nilai-nilai tersebut diantara angka nol dan satu $(0<\mathrm{x}<1)$, maka lokasi wisata tersebut masih memiliki nilai dampak ekonomi yang rendah, dan

c. Apabila nilai-nilai tersebut lebih besar atau sama dengan satu $(\geq 1)$, maka lokasi wisata tersebut telah mampu memberikan dampak ekonomi terhadap kegiatan wisatanya.

\section{PEMBAHASAN}

\subsection{Dampak langsung (Direct impact)}

Dampak ekonomi langsung dari kegiatan wisata hiu paus di Desa Batubarani ditimbulkan dari interaksi ekonomi yang terjadi antara wisatawan dengan masyarakat lokal yang memiliki unit usaha di lokasi wisata ini. Unit usaha lokal yang terdapat di lingkungan Wisata hiu paus sebagian besar merupakan unit usaha dengan skala kecil dan hanya ramai dikunjungi pada akhir pekan dan hari libur. Unit usaha lokal diantaranya perahu katinting tanpa motor, warung dan warung makan, serta penjulan hasil limbah udang. Sebaran jumlah unit usaha dapat dilihat pada Tabel 1. 
Tabel 1. Sebaran jenis unit usaha lokal di lingkungan wisata Hiu Paus

\begin{tabular}{lc}
\hline \multicolumn{1}{c}{ Jenis unit usaha } & Jumlah (unit) \\
\hline Penyewaan perahu & 60 \\
Penjualan Limbah Udang & 1 \\
Warung Makan & 10 \\
Warung & 10 \\
\hline Total & 81 \\
\hline
\end{tabular}

Dampak ekonomi langsung dari pengeluaran wisatawan dirasakan langsung oleh pemilik unit usaha. Dampak ekonomi ini berupa pendapatan pemilik dari unit usaha. Sebaran pendapatan responden pemilik unit usaha dan dampak langsung yang dirasakan di wisata Hiu Paus dapat dilihat pada Tabel berikut .

Tabel 2. Sebaran pendapatan responden pemilik unit usaha dan dampak langsung yang dirasakan dalam waktu 1 minggu

\begin{tabular}{lccc}
\hline \multicolumn{1}{c}{ Jenis Usaha } & $\begin{array}{c}\text { Rata-Rata Pendapatan } \\
\text { (Rp.) }\end{array}$ & $\begin{array}{c}\text { Jumlah } \\
\text { (Unit) }\end{array}$ & $\begin{array}{c}\text { Total Pendapatan } \\
\text { (Rp.) }\end{array}$ \\
\hline Perahu & 900.000 & 60 & 54.000 .000 \\
Limbah Udang & 3.000 .000 & 1 & 3.000 .000 \\
Warung Makan & 350.000 & 10 & 3.500 .000 \\
Warung & 350.000 & 10 & 3.500 .000 \\
\hline Total Penerimaan (Dampak Langsung) & & 63.000 .000 \\
\hline
\end{tabular}

Berdasarkan pada Tabel di atas, dapat dilihat bahwa unit usaha penyewaan perahu memiliki pendapatan paling besar diantara jenis unit usaha lainnya yang berada di wisata Hiu Paus dengan rata-rata pendapatan Rp. 900.000 setiap minggunya, sedangkan pendapatan terkecil yaitu pada unit usaha warung dan warung makanyang hanya memiliki rata-rata pendapatan sebesar Rp. 200.000 perbulannya. Berdasarkan Tabel 5, penerimaan rata-rata dari keseluruhan responden unit usaha yaitu sebesar Rp. 4.031.944 perbulan, dari total penerimaan tersebut terdapat pendapatan pemilik unit usaha (dampak ekonomi langsung) yang dirasakan oleh pemilik unit usaha yaitu sebesar Rp. 350.000 dalam setiap minggu. Dampak langsung dari keseluruhan unit usaha yaitu sebesar Rp. 63.000.000 dalam setiap minggunya

\subsection{Dampak tidak langsung (Indirect impact)}

Dampak ekonomi tidak langsung (indirect impact) dapat dilihat dari pembelian bahan baku untuk keperluan unit usaha, transportasi lokal, dan upah tenaga kerja yang bekerja pada unit usaha yang berada di sekitar lokasi wisata (Monoarfa, 2016). Tenaga kerja yang bekerja di unit usaha adalah penerima dampak tidak langsung dari pengeluaran wisatawan, yaitu berupa upah yang diterimanya dari unit usaha tempat mereka bekerja (Belinda, 2013 dalam Monoarfa, 2016). Adapun biaya-biaya yang dikeluarkan oleh unit usaha di dalam lokasi wisata dan dampak tidak langsung yang dirasakan dari keberadaan Wisata Hiu Paus dapat dilihat pada Tabel berikut . 
Tabel 3. Sebaran total biaya unit usaha di dalam lokasi wisata dan dampak ekonomi tidak langsung yang dirasakan akibat keberadaan wisata Hiu Paus

\begin{tabular}{|c|c|c|c|c|c|c|}
\hline \multirow[t]{2}{*}{ Jenis Usaha } & $\begin{array}{c}\text { Jumlah } \\
\text { Unit } \\
\text { Usaha }\end{array}$ & $\begin{array}{l}\text { Upah TK } \\
\text { (Rp.) }\end{array}$ & $\begin{array}{l}\text { Bahan Baku } \\
\quad \text { (Rp.) }\end{array}$ & $\begin{array}{l}\text { Transportasi } \\
\text { (Rp.) }\end{array}$ & $\begin{array}{l}\text { Total Biaya } \\
\quad \text { (Rp.) }\end{array}$ & Total (Rp.) \\
\hline & (1) & (2) & (3) & (4) & $(5=2+3+4)$ & $(6=1 * 5)$ \\
\hline Perahu & 60 & 450.000 & 0 & 0 & 450.000 & 27.000 .000 \\
\hline Limbah Udang & 1 & 600.000 & 1.500 .000 & 0 & 2.100 .000 & 2.100 .000 \\
\hline Warung Makan & 10 & 150.000 & 200.000 & 0 & 350.000 & 3.500 .000 \\
\hline Warung & 10 & 200.000 & 150.000 & 0 & 3350.000 & 3.500 .000 \\
\hline & & ll Dampak & idak Langsung & & & 36.100 .000 \\
\hline
\end{tabular}

Tenaga kerja sekitar merupakan pihak yang secara tidak langsung mendapatkan dampak ekonomi dari keberadaan obyek wisata yaitu melalui pendapatan mereka yang mereka dapat dari pemilik unit usaha sekitar lokasi wisata. Begitupun dengan kebutuhan untuk pembelian bahan baku bagi unit usaha seperti kios makanan dan minuman mereka dapat memenuhi kebutuhan bahan baku tersebut di dalam kawasan wisata. Dapat dilihat pada Tabel di atas, untuk upah tenaga kerja yang diperoleh berbeda-beda tergantung dengan jenis unit usaha tempat mereka bekerja. Dampak tidak langsung yang berupa upah (pendapatan) tenaga kerja dirasakan paling besar yaitu dari tenaga kerja pemandu perahu yaitu rata-rata sebesar Rp. 450.000 di setiap minggunya.

Berdasarkan Tabel di atas, dapat dilihat bahwa besarnya dampak ekonomi tidak langsung yang dapat dirasakan dari keberadaan wisata hiu paus berbeda-beda tergantung dari jenis unit usahanya. Dampak ekonomi tidak langsung yang dirasakan paling besar yaitu dari jenis unit usaha limbah udang, hal ini disebabkan karena keindahan hiu paus akan terlihat jika hiu paus naik kepermukaan yang dipancing dengan limbah udang.

\subsection{Nilai multiplier effect dari pengeluaran responden wisatawan}

Dampak ekonomi terhadap kawasan wisata diukur menggunakan nilai efek penggganda (Multiplier Effect). Efek pengganda dapat dilihat dari jumlah pengeluaran wisatawan selama melakukan wisata di Wisata Hiu Paus Batubarani. Terdapat tiga ukuran nilai pengganda yang dapat diestimasi, yaitu: (1) Keynesian Income Multiplier merupakan nilai yang diperoleh dari dampak langsung atas pengeluaran wisatawan, (2) Ratio Income Multiplier Tipe I, merupakan nilai yang diperoleh dari dampak tidak langsung atas pengeluaran wisatawan, dan (3) Ratio Income Multiplier Tipe II, merupakan nilai yang diperoleh dari dampak lanjutan (META, 2001 dalam Nurfiana, 2013). Nilai pengganda ketiga tipe tersebut dapat dilihat pada Tabel 4. 
Tabel 4. Nilai pengganda (Multiplier Effect) dari arus uang yang terjadi di wisata Hiu Paus

\begin{tabular}{|c|c|}
\hline Multiplier & Nilai \\
\hline Keynesian Income Multiplier & 1.52 \\
\hline Ratio Income Multiplier Tipe 1 & 1,61 \\
\hline Ratio Income Multiplier Tipe 2 & 1,97 \\
\hline
\end{tabular}

Berdasarkan data yang diperoleh untuk menentukan besarnya dampak ekonomi di wisata hiu Paus Batubarani, diperoleh nilai Keynesian Multiplier Effect yaitu sebesar 1.52 yang artinya setiap terjadi peningkatan pengeluaran wisatawan sebesar satu rupiah, maka akan berdampak langsung sebesar 1.52 rupiah terhadap perekonomian masyarakat sekitar. Nilai Ratio Income Multiplier Tipe 1 adalah sebesar 1,21 yang artinya setiap peningkatan satu rupiah pada penerimaan unit usaha akan mengakibatkan peningkatan sebesar 1,61 rupiah terhadap pendapatan tenaga kerja sekitar (berupa pendapatan pemilik usaha dan upah tenaga kerja). Selanjutnya nilai yang diperoleh dari Ratio Income Multiplier Tipe 2 sebesar 1,97 yang artinya apabila terjadi peningkatan sebesar satu rupiah pada penerimaan unit usaha diduga akan mengakibatkan peningkatan sebesar 1,97 rupiah pada pendapatan pemilik unit usaha, pendapatan tenaga kerja, dan pengeluaran konsumsi tenaga kerja ditingkat lokal.

Dampak ekonomi yang terjadi pada penelitian ini dikatakan tinggi , dapat dilihat dari nilai Keynesian Income Multiplier yang diperoleh yaitu sebesar 0,99. Menurut Dritasto (2013) apabila nilai tersebut terletak diantara nol sampai dengan satu $(0<\mathrm{x}<$ 1), maka lokasi wisata tersebut memiliki nilai dampak ekonomi yang rendah. Hal ini dikarenakan wisatawan yang datang ke lokasi ini lebih cenderung mengeluarkan pengeluarannya di luar obyek wisata. Dengan kata lain, proporsi kebocoran/pengeluaran di luar lokasi wisata lebih besar dari pada proporsi pengeluarannya di lokasi wisata. Sedangkan Ratio Income Multiplier Tipe 1 dan Ratio Income Multiplier Tipe II dapat dikatakan telah memberikan dampak ekonomi terhadap kegiatan wisata karena nilai Ratio Income Multiplier Tipe 1 dan Tipe II sudah lebih besar atau sama dengan satu ( $\geq$ 1). Kurangnya pengetahuan dan kreatifitas masyarakat dalam melakukan kegiatan usaha serta perhatian pemerintah yang belum maksimal menjadi salah satu faktor rendahnya perputaran uang.

\section{KESIMPULAN}

Berdasarkan hasil penelitian, maka dapat disimpulkan dampak ekonomi wisata bahari terhadap pendapatan masyarakat di Desa Batubarani telah memberikan dampak ekonomi kepada masyarakat walaupun dampak yang dirasakan berada pada kategori rendah dan belum dirasakan secara merata oleh masyarakat. Nilai Keynesian Income Multiplier adalah 1.52, Ratio Income Multiplier Tipe 1 adalah 1,61 dan Ratio Income Multiplier Tipe 2 adalah 1,97. 


\section{DAFTAR PUSTAKA}

Anggraini, R. (2014). Pengembangan Objek Wisata Pantai Pasir Padi Sebagai Daya Tarik Wisata di Kota Pangkalpinang. Tugas Akhir. Universitas Gajah Mada. Yogyakarta.

Belinda, N. (2013). Analisis Dampak Berganda (Multiplier Effect) Pemanfaatan Wisata Alam Tanjung Mutiara di Danau Singkarak Kabupaten Tanah Datar. Skripsi. Departemen EkonomiSumberdaya dan Lingkungan.Fakultas Ekonomi dan Manajemen. Institut Pertanian Bogor.

Dritasto, A., \& Annisa A. A. (2013). Analisis Dampak Ekonomi Wisata Bahari Terhadap Pendapatan Masyarakat di Pulau Tidung. Reka LokaJurnal Online Institut Teknologi Nasional, Itenas | No.x | Vol. xxJanuari 2013. Institut Teknologi Nasional.

Gautama, IG. (2011). Evaluasi Perkembangan Wisata Bahari di Pantai Sanur. Tesis. Program Magister. Program Studi Kajian Pariwisata. Program Pasca Sarjana Universitas Udayana. Denpasar.

Milasari. (2010). AnalisisDampak Ekonomi Kegiatan Wisata Alam (Studi Kasus : Taman Wisata Tirta Sanita, Kabupaten Bogor). Skripi. Departemen EkonomiSumberdaya Dan Lingkungan. Fakultas Ekonomi dan Manajemen. Institut Pertanian Bogor.

Nurfiana, E. (2013). Analisis Dampak Ekonomi dan Lingkungan Kegiatan Wisata di Taman Wisata Alam Grojogan Sewu, Kabupaten Karanganyar, Provinsi Jawa Tengah Terhadap Masyarakat Sekitar. Skripsi. Departemen Ekonomi Sumberdaya dan Lingkungan. Fakultas Ekonomi dan Manajemen. Institut Pertanian Bogor.

Prasetio, B. (2011). Analisis Dampak Ekonomi Wisata Bahari Terhadap Masyarakat di Pulau Pramuka Taman Nasional Kepulauan Seribu. Skripsi. Departemen Konservasi Sumberdaya Hutan Dan Ekowisata. Fakultas Kehutanan. Institut Pertanian Bogor. 